\title{
MEMAKNAI INKULTURASI DALAM PENDIDIKAN SENI DAN KONSERVASI
}

\author{
Dody Candra Harwanto \\ Prodi Musik Gereja, Sekolah Tinggi Theologia Abdiel \\ Jl. Pangeran Diponegoro No.233, Ungaran, Kabupaten Semarang, Jawa Tengah 50511 \\ dcharwanto@gmail.com
}

\begin{abstract}
The gradual flow of globalization influences the existence of traditional arts and cultural identities of an area that is starting to fade. In overcoming these conditions, one of the efforts that can be done is through art education and cultural conservation into new forms such as inculturation. The phenomenon of inculturation provides space for the process of art education through the development of artistic expertise, creation, and appreciation using traditional arts. In addition, efforts to conserve culture through the use of traditional arts in every procession of worship, can be a force that animates and renews the culture intensively. The pursuit of democratic cultural integration, the wealth of traditional arts in an area with all its uniqueness, beauty and cultural values can be proud of, maintained, developed and preserved, so that it can become the identity of an area and even a nation.
\end{abstract}

Keywords: inculturation; conservation; art education; cultural integration

\section{Pendahuluan}

Indonesia memiliki berbagai bentuk kebudayaan yang berbeda-beda di setiap daerah. Kebudayaansecara tidak sadar membentuk seseorang dalam melakukan segala perilakunya untuk sesuai dengan budaya yang ada pada tempat kelahirannya, oleh karena salah satu dari wujud kebudayaan adalah perilaku-perilaku atau tindakan-tindakan yang membentuk suatu pola kebiasaan dari masyarakat dalam berbudaya. Implikasinya bahwa individu dalam suatu kelompok sosialnya, akan berupaya untuk menyesuaikan pola perilaku masyarakatnya sebagai cara bereksistensi.

Seperti yang dijelaskan Koentjaraningrat (1990, p. 186) bahwa terdapat tiga wujud kebudayaan yaitu: (1) suatu kompleks dari ide-ide, gagasan, nilai-nilai, norma-norma, peraturan, dan sebagainya; (2) suatu kompleks aktivitas serta tindakan berpola dari manusia dalam masyarakat; dan (3) benda-benda hasil karya manusia. Sehingga dapat dilihat bahwa ketiga wujud kebudayan tersebut membentuk satu kesatuan yang tidak dapat dipisahkan dan berkesinambungan. Dimulai dari suatu gagasan atau nilai, membentuk seseorang dalam berperilaku untuk kemudian mempengaruhi seseorang dalam menghasilkan benda-benda hasil karya manusia dalam kebudayaannya. 
Benda-benda hasil karya manusia tentunya berbentuk material ataupun fisik, yang salah satu contohnya adalah kesenian. Kesenian terbentuk dari sebuah gagasan atau nilainilai yang dimiliki oleh seorang pencipta seni (seniman) serta berbagai tindakan yang mempengaruhi hasil karya seni seorang seniman. Sehingga sangatlah mungkin jika kesenian dari berbagai daerah memiliki karakteristik yang berbeda-beda dengan kesenian yang ada pada daerah lain. Sebagai contoh musik gamelan Jawa (Jawa) yang memiliki nuansa ketenangan dan membawa seseorang dalam imajinasi penuh asosiatif serta kontemplatif batin Jawa, memiliki perbedaan dengan musik Cianjuran (Sunda) yang memiliki nuansa seperti penuh syukur, terbuka, melayang, dan menelusuri sawah.

Dimensi nuansa dari karakteristik suatu seni (musik) tertentu dihasilkan dari pengalaman pencipta dalam menghayati kehidupannya, dan pada gilirannya memiliki korelasi misterius serta menarik dengan latar belakang sosial budayanya (Sugiharto, 2013). Kesenian-kesenian tradisional yang berkelindan dalam pengalaman perasaan, imajinasi, gagasan, dan kerangka pikir budaya suatu daerah tertentu, menjadi memprihatinkan ketika generasi penerusnya tidak memiliki sikap apresiatif yang baik terhadap keseniannya sendiri oleh karena adanya perubahan sosial budaya.

Zaman yang dapat disebut sebagai era postmodern, ditandai dengan tumbuhnya budaya massa dan budaya populer. Dalam realitas kebudayaan saat konsumsi mengalahkan produksi, nilai-tanda dan nilai-simbol mengalahkan nilai-guna dan nilai-tukar, penampilan menjadi tujuan, tuntutan mengejar keuntungan adalah satu-satunya pegangan, maka tak pelak, budaya massa dan budaya populer adalah jawaban dari masyarakat yang demikian (Sunarto, 2014, p. 111). Maka tidak mengherankan jika dalam masyarakat yang dihidupi budaya massa dan budaya populer menumbuhkan suatu simbol-simbol dan aktivitas kebudayaan baru.

Pemikiran untuk selalu mengejar keuntungan dari suatu masyarakat menyebabkan kesenian-kesenian tradisional semakin sulit dalam menjaga eksistensinya, oleh karena tidak mampu memberikan keuntungan kepada penonton atau seniman atau bahkan produsen musik. Di lain pihak, musik pop maupun dangdut yang banyak memberikan keuntungan pada penonton atau seniman bahkan produsen musik, menyebabkan musik pop ataupun dangdut dapat tetap eksis seperti yang dapat dilihat dalam realitas sosial dewasa ini.

Realitas yang terjadi dapat dilihat bahwa musik-musik pop lebih 'berkuasa' jika dibandingkan dengan musik-musik tradisional (kesenian daerah). Hal tersebut dikarenakan 
cara pemanfaatan produk (musik pop) yang dipaksakan oleh tatanan ekonomi dominan, menyebabkan pola-pola konsumsi musik pop tersebut menghasilkan suatu konsensus yang tanpa disadari oleh masyarakat. Kondisi tersebut menghasilkan ketimpangan pada eksistensi musik pop (Barat) dengan musik tradisional yang dimiliki pada suatu daerah.

Semakin sulitnya kesenian-kesenian tradisional untuk mampu bersaing dengan musik pop, menimbulkan kekhawatiran pada kebudayaan suatu daerah bahkan bangsa Indonesia yang lahir dari sebuah keberagaman melalui falsafahnya yaitu Bhinneka Tunggal Ika. Para pendiri bangsa Indonesia menyadari adanya keberagaman budaya untuk dapat menjadi satu kekuatan menuju keIndonesiaan. Namun jika kesenian-kesenian tradisional suatu daerah dengan berbagai nilai-nilai budaya, keunikan, dan keindahannya secara gradual mulai hilang, apakah keIndonesiaan akan tetap ada dengan falsafahnya?

Upaya untuk tetap menjaga eksistensi kesenian-kesenian tradisional, maka diperlukan suatu pelestarian budaya. Wacana-wacana pelestarian merupakan konsekuensi reflektif dari banyaknya kebiasaan masyarakat konsumtif yang menerima berbagai budayabudaya dari luar, sehingga menimbulkan suatu kerusakan bahkan kepunahan dari segala sesuatu yang diambil terus menerus. Pemahaman-pemahaman pelestarian ini membentuk suatu konsep yang dinamakan konservasi. Secara umum, konservasi mempunyai arti pelestarian yaitu melestarikan/ mengawetkan daya dukung, mutu, fungsi, dan kemampuan lingkungan secara seimbang (MIPL, 2010, p. 39).

Keberadaan konservasi bukan hanya dilihat sebagai bentuk upaya pelestarian alam, namun dapat juga pelestarian budaya. Seperti yang dikemukakan oleh Leksono, Rustaman, \& Redjeki (2013, p. 409) bahwa terdapat empat jenis karakter konservasi yang dapat dikembangkan selama proses pendidikan, yaitu (1) pendidikan karakter berbasis nilai budaya, yang merupakan kebenaran wahyu Tuhan (konservasi moral); (2) pendidikan karakter berbasis budaya, antara lain yang berupa budi pekerti, pancasila, apresasi sastra, keteladanan tokoh-tokoh sejarah dan para pemimpin bangsa (konservasi budaya); (3) pendidikan karakter berbasis lingkungan (konservasi lingkungan), dan (4) pendidikan karakter berbasis potensi diri, yaitu sikap pribadi, hasil proses kesadaran pemberdayaan potensi diri yang diarahkan untuk meningkatkan kualitas pendidikan (konservasi humanis). Pada proses pendidikan khususnya seni, karakter konservasi dapat tercermin dari poin yang kedua yaitu sebagai konservasi budaya, dikarenakan seni merupakan salah satu unsur dari budaya. 
Pendidikan seni dapat dijadikan sebagai media konservasi budaya yang memiliki dua konsep yaitu pendidikan dalam seni (Education in Art) dan pendidikan melalui seni (Education Through Art) (Soehardjo, 2005, p. 3). Yang pertama merupakan aset budaya dalam rangka pelestariannya, dan yang kedua merupakan aset pendidikan yang misinya untuk memanfaatkan seni supaya berfungsi sebagai sarana menumbuh dan mengembangkan individu dalam rangka mempersiapkan hari depannya.

Dalam konteks tersebut pendidikan tidak hanya melulu dapat dilakukan di sekolah formal saja, namun juga dapat dilakukan di dalam keluarga, tempat kursus, ataupun masyarakat. Oleh karena pada hakikatnya, pendidikan mencakup kegiatan mendidik, mengajar, dan melatih (Gandhi, 2011, p. 67). Pada pendidikan dalam seni, keseniankesenian tradisional dapat digunakan sebagai benda untuk mengembangkan skill individu. Lalu pada pendidikan melalui seni, kesenian-kesenian dapat digunakan sebagai alat atau media untuk penanaman maupun ekspresi nilai-nilai keindahan dan budaya serta pengalaman estetis yang ada pada kesenian daerah tersebut.

Upaya nyata dalam melestarikan kesenian daerah, salah satu contohnya dapat dilihat dari sebuah fenomena yang terjadi di gereja GITJ Margorejo tepatnya di desa Badegan kecamatan Margorejo kabupaten Pati. Pada sebuah peribadatan di gereja GITJ Margorejo menggunakan alat musik gamelan Jawa sebagai alat musik pengiring dalam kegiatan peribadatan bagi umat Kristiani. Seperti diketahui bahwa iringan musik pada peribadatan di gereja pada dasarnya berasal dari Barat yang memakai Organ atau alat musik diatonis, karena ajaran agama Kristen berasal dari Barat, sehingga lagu, tata cara ibadah (liturgi), dan iringan musik secara tidak langsung menggunakan budaya Barat.

Proses digunakannya alat musik gamelan Jawa dalam kegiatan peribadatan di gereja dapat disebut inkulturasi. Inkulturasi berasal dari kata "in" dan "culture", yang berarti "masuk ke dalam kebudayaan" atau proses berakar dalam kebudayaan (Hadi, 2006, p. 40). Sedangkan Prier (2009) menjelaskan bahwa "inkulturasi merupakan suatu proses pengungkapan suatu nilai dalam wujud kebudayaan tertentu" (p. 71).

Istilah inkulturasi berasal dari lingkungan teologi misi. Istilah ini mulai berkembang sesudah Konsili Vatikan II bersama dengan berbagai macam istilah lain seperti yang telah disebutkan (Martasudjita, 1998, p. 26). Muda (1992) menjelaskan “inkulturasi adalah suatu proses dimana persekutuan gereja menghidupi iman dan pengalaman kristennya dalam konteks kebudayaan tertentu, sehingga penghayatan ini tidak dapat diungkapkan lewat elemen-elemen kebudayaan setempat, melainkan menjadi satu 
kekuatan yang menjiwai, membentuk, dan secara mendalam membaharui kebudayaan itu sendiri” (p. 34-35). Penjelasan yang sudah dipaparkan dapat diinterpretasikan bahwa inkulturasi adalah upaya pembauran khususnya religi ke dalam kebudayaan setempat dengan mengambil unsur-unsur kebudayaannya yang dapat dijadikan suatu kekuatan yang menjiwai, dan secara mendalam membaharui kebudayaan tersebut.

Upaya-upaya dalam menggunakan, menjaga, dan melestarikan kesenian-kesenian daerah bukan merupakan upaya menolak seni modern yang ada pada masyarakat namun lebih kepada sikap kebijaksanaan dalam menerima berbagai budaya yang masuk dan mencegah hilangnya keunikan, nilai-nilai budaya, dan keindahan pada kesenian suatu daerah. Sehingga melalui itu, identitas atau jati diri tetap dimiliki oleh suatu daerah bahkan bangsa Indonesia, bukan sebaliknya menjadi suatu identitas yang kabur dan tentatif.

Masih banyak manfaat-manfaat yang dapat diambil dari sebuah pelestarian budaya yang tentunya memiliki berbagai tujuan-tujuan yang baik. Dari berbagai pemaparan di atas, maka pada pembahasan ini akan melihat suatu bentuk pendidikan seni dan konservasi budaya dari fenomena inkulturasi gamelan Jawa di gereja GITJ Margorejo Pati. Diharapkan dapat tumbuh sikap apresiatif terhadap kesenian tradisional dan menjadi pemantik pemikiran dalam melakukan berbagai upaya-upaya pelestarian budaya yang lain. Kesenian tradisional yang digunakan sebagai contoh dalam usaha pelestarian adalah gamelan Jawa sebagai pendidikan seni dan konservasi budaya.

\section{Gamelan Jawa}

Tindakan-tindakan konservatif pada kesenian-kesenian tradisional seperti gamelan Jawa menjadi sesuatu yang penting untuk dilakukan, karena sudah terlalu banyak masyarakat mengkonsumsi musik-musik Barat, pop, kontemporer dan sudah mulai menjauh dari keseniannya sendiri. Musik gamelan Jawa biasa digunakan untuk menyebut karawitan. Ditinjau dari etimologi, gamelan berasal dari kata gamel yang artinya pukul, sehingga gamelan dapat diartikan instrumen yang berbunyinya dengan cara dipukul. Ditinjau dari maknanya, maka gamelan berarti kelompok-kelompok instrumen yang membentuk kesatuan jenis tabuhan (Soeroso, 1985, p. 2). Seni karawitan atau gamelan Jawa, dalam penyajiannya merupakan hasil perpaduan antara permainan instrumen dengan instrumen, instrumen dengan vokal, serta berlaras slendro, dan atau pelog. Alat musik tradisional ini biasa digunakan sebagai pelengkap berbagai kegiatan ritual, kesenian, dan hiburan oleh masyarakat (Bram Palgunadi, 2002, p. 1). 
Nilai-nilai keindahan dalam karya musik gamelan Jawa, dapat digali dari struktur bunyi musik yang dihasilkan. Nilai keindahan bunyi-bunyi musik itu dapat terungkap dalam terminologi istilah yang secara turun-temurun diteruskan melalui tradisi masyarakat pendukungnya. Keindahan bunyi gamelan dapat terungkap dari konsep pathet, laras, manis, mipil, nibani, wiled, lombo, wiromo dobel, wiromo engkel, gembyang, sampak, lungguh, seleh dan masih banyak lagi. Konsep-konsep bunyi keindahan itulah yang perlu diajarkan dan mengalami keindahan bunyi pada gamelan Jawa, merasakan apa yang disebut dengan seleh dalam memainkan gong, merasakan dan mengalami letak keindahan yang disebut wiromo dobel, ini yang termasuk salah satu keindahan tersendiri dalam musik gamelan Jawa. Sewaktu para pengrawit (pemain gamelan) memainkan ricikan gamelan dengan tempo yang cepat, sinden (penyanyi) tidak menyanyikan dengan tempo yang cepat juga tetapi justru sebaliknya, sinden harus menyanyi dengan tempo yang lebih lambat, sehingga inilah keindahan yang menjadi kekhasan tersendiri dan keduanya tetap menjadi harmonis.

Paradigma keindahan dipelajari dengan bermain gamelan Jawa dan merasakan konsep-konsep keindahan itu. Nilai keindahan tidak diukur dari nilai-nilai non tradisinya, tetapi berdasarkan rasa keindahan menurut masyarakatnya. Masyarakat pendukungnya sudah memiliki kriteria-kriteria tersendiri tentang nilai-nilai etis dan estetis dalam bermain gamelan Jawa. Seperti yang dikemukakan oleh Harahap (2001) bahwa dalam setiap musik etnis memiliki ukuran-ukuran keindahan sendiri-sendiri, maka Harahap menulis sebagai berikut: "1. Musik hanya bisa dipahami berdasarkan konteks kultural dimana musik itu berada; 2. Musik tidak dapat diberi nilai baik atau buruk, karena masing-masing masyarakat memiliki kaidah estetis maupun etis tersendiri terhadap musiknya; ..." (p. 3). Dengan demikian teori tentang melodi, harmoni dan lain sebagainya bukan dilihat dari ukuran melodi dan harmoni dalam musik diatonis (Barat), sebab hal tersebut tidak akan ditemukan keindahan akor dengan istilah mayor, minor, diminished, dan augmented yang ada pada teori musik Barat, tetapi ditemukan nilai-nilai keindahan lain dengan konsepkonsep terminologi yang lain pula menurut pemahaman budaya masyarakatnya.

\section{Inkulturasi dalam Pendidikan Seni (Tradisional)}

Proses masuknya gamelan Jawa di gereja GITJ Margorejo Pati sebagai musik pengiring mampu memberikan nuansa yang berbeda dari peribadatan pada umumnya, karena pada dasarnya dalam peribadatan umat kristiani di gereja menggunakan alat musik 
organ atau piano yang notabene agama Kristen berasal dari Barat. Seperti yang dikemukakan oleh Prier (2002) bahwa dalam ibadah selama abad 19, permainan organ terbatas pada iringan nyanyian gregorian/ koral serta Choralvorspiel/ Postludium sederhana. Perkembangan organ Gereja pada awal abad 19 pun macet. Dibandingkan dengan piano yang mengalami peningkatan ekspresi, organ dirasa statis (p. 36). Proses bercampurnya gamelan Jawa pada sebuah peribadatan tersebut dapat dinamakan inkulturasi.

Pada proses inkulturasi gamelan Jawa yang dimulai sejak tahun 2002 di gereja GITJ Margorejo Pati, dapat memberikan "angin segar" terhadap eksistensi kesenian tradisional khususnya gamelan Jawa. Penggunaan gamelan Jawa sebagai alat musik pengiring dalam peribadatan di gereja mampu memberikan nuansa kejawen (kejawaan) pada jemaat gereja dalam menghayati dan menyanyikan lagu-lagu rohani untuk menghubungkan diri dengan Tuhan. Prosesi/ liturgi ibadah di gereja yang menyesuaikan diri dengan latar belakang kebudayaan tertentu yang dalam hal ini adalah penggunaan gamelan Jawa di gereja GITJ Margorejo Pati sebagai musik pengiring merupakan salah satu bentuk musik liturgi inkulturatif (Bakok, 2013).

Estetika gamelan Jawa yang memiliki karakteristik kehalusan, kelemahlembutan memberikan kesesuaian hati dan keindahan pada jemaat di gereja yang berlatarbelakang budaya orang Jawa. Seperti yang dikemukakan Sumarsam (2003) bahwa gamelan Jawa sebagai salah satu cabang seni yang hidup, bertahan, dan berkembang di Jawa (Indonesia), mempunyai fungsi yang sangat penting dalam kehidupan masyarakat. Baik dipandang dari sisi tekstual maupun kontekstual, gamelan Jawa selalu berhubungan erat dengan masyarakat. Setiap masyarakat mempunyai peristiwa yang ditandai oleh musik "gamelan Jawa" yang dapat membangkitkan kebersamaan warganya dan meningatkan kesatuan mereka (p. 2).

Inkulturasi sebagai suatu upaya pembauran agama ke dalam kebudayaan setempat untuk dijadikan suatu kekuatan yang menjiwai, dan secara mendalam memperbaharui kebudayaan tersebut yang ditandai dengan digunakannya gamelan Jawa dalam sebuah peribadatan. Sehingga di dalam sebuah fenomena budaya tersebut secara implisit ditemukan suatu tindakan-tindakan yang di satu sisi menuju pada konsep pendidikan seni dan di sisi lain pada konservasi. Pendidikan seni dapat ditinjau dari dua konsepnya yaitu (1) pendidikan dalam seni dan (2) pendidikan melalui seni. 
Penggunaan gamelan Jawa pada peribadatan di gereja menimbulkan upaya dari para pemimpin-pemimpin gereja untuk melatih generasi muda gereja untuk bermain gamelan Jawa sebagai upaya regenerasi pemain gamelan Jawa di gereja. Proses penularan kesenian inilah yang merupakan konsep dari pendidikan dalam seni dengan tujuan untuk melatih dan mengembangkan keahlian (skill) dalam berkesenian. Di lain pihak, bahwa pendidikan dalam seni yang menggunakan kesenian tradisional sebagai objeknya dapat menjadi salah satu upaya untuk menjaga, mengembangkan, dan melestarikan produk budaya. Secara tidak langsung pendekatan pendidikan konservatif tersebut merupakan proses enkulturasi (proses pembudayaan) yang dilakukan dalam rangka melestarikan dan meneruskan nilai-nilai budaya antargenerasi dalam menjaga tatanan sosial budaya.

Sedangkan pendidikan melalui seni dapat dilihat dari penggunaan seni (gamelan Jawa) sebagai media kreasi dan apresiasi. Kegiatan apresiasi terhadap seni tradisional merupakan kegiatan menghayati secara aktif berbagai kesan-kesan yang ditimbulkan dari benda seni, sehingga mampu menghasilkan pengalaman estetik tertentu. Melalui pengalaman estetik tersebut diharapkan para generasi penerus dapat memiliki sikap empati terhadap kesenian tradisional yang sedang diapresiasi. Pengalaman estetik melalui kesenian tradisional dibutuhkan oleh karena berbagai media elektronik seperti televisi lebih banyak menampilkan kesenian-kesenian modern yang dapat mempengaruhi selera masyarakat dan cenderung menghasilkan apresiasi terhadap kesenian-kesenian modern daripada kesenian tradisional.

Bentuk karya seni itu diwujudkan oleh seniman melalui kreativitas artistik. Ini berarti bahwa kegiatan penciptaan seni merupakan kegiatan kreatif (Lansing, 1969, p. 32). Seni sebagai media kreasi merupakan aktivitas yang dapat ditemukan dalam proses penciptaan karya seni. Para jemaat gereja dapat berperan aktif dan berkreativitas yang dimulai dengan imajinasi/ intuisi dalam mencari gagasan untuk dikonstruksi dan diekspresikan melalui media seni, hingga pada akhirnya menjadi sebuah karya seni yang dapat dinikmati. Terjadinya proses kreativitas melalui kesenian tradisional tersebut memberikan suatu hal yang baik bagi perkembangan eksistensi kesenian tradisional dan suasana dalam proses peribadatan di gereja yang sesuai dengan konteks budayanya.

Seni dalam ritual agama merupakan simbol ekspresi jiwa manusia dalam menyatakan hubungan dirinya kepada Tuhan dan bersifat transendental. Peristiwa tersebut dimaknai sebagai sesuatu yang sakral dan khusus, sehingga manusia berupaya melakukan tata cara yang baik dalam proses ibadah tersebut. Peranan inkulturasi ini menjadi penting 
dikarenakan prosesi peribadatan diekspresikan melalui cara-cara yang dapat dimengerti oleh umat sesuai dengan konteks budayanya, sehingga menjadi kekuatan bagi masyarakat dalam mengungkapkan dan mewujudkan iman dalam kehidupan sehari-hari menurut situasi dan kondisi aktual setempat (Martasudjita, 2010).

\section{Inkulturasi dalam Konservasi (Budaya)}

Inkulturasi merupakan tindakan konservasi (budaya), artinya bahwa dalam proses inkulturasi gamelan Jawa di gereja GITJ Margorejo Pati secara implisit merupakan sebuah tindakan pelestarian. Pelestarian dapat dilihat dari penggunaan gamelan Jawa itu sendiri sebagai musik pengiring pada proses peribadatan di gereja. Gamelan Jawa yang selalu hadir pada setiap peribadatan (setiap hari minggu) di gereja yang di dalamnya meliputi sekumpulan anak-anak, remaja, dewasa, dan orang tua dapat memberikan dampak positif terhadap eksistensi gamelan Jawa sebagai kesenian daerah orang Jawa. Karena umumnya pertunjukan gamelan Jawa hanya dapat ditemukan pada acara-acara tertentu saja dan minat penontonnya pun kebanyakan para orang tua. Sehingga dengan keberadaan gamelan Jawa di gereja pada setiap minggunya dapat membentuk tindakan pelestarian terhadap gamelan Jawa beserta nilai-nilai budaya yang ada di dalamnya dan memberikan pengalaman estetis terhadap kesenian tradisional bagi anak-anak, remaja, dan dewasa yang sudah mulai sedikit didapatkan dalam lingkungannya.

Inkulturasi sebagai suatu bentuk fenomena budaya dapat dimaknai sebagai upaya asimilasi dan integrasi budaya terhadap berbagai budaya-budaya luar yang masuk dan mempengaruhi. Pendidikan melalui seni tradisional yang terjadi pada proses inkulturasi, menunjukkan adanya dialog antara yang global dengan yang lokal secara berkelindan, sehingga memungkinkan suatu masyarakat untuk mampu mempertahankan identitas dan jati dirinya (Agustini, 2017). Orientasi mengenai kesadaran pendidikan seni melalui seni tradisional menjadi tujuan yang penting untuk memelihara kesadaran sosial, menyalurkan warisan budaya, dan mengapresiasi seni sebagai gejala budaya dengan segala nilai-nilai di dalamnya (Chapman 1978; Eisner 1972). Diharapkan melalui paradigma pendidikan seni dan sikap konservasi tersebut selalu dapat dilakukan dengan berbagai implikasi dan bentuknya dalam menghadapi, menyesuaikan, serta mengintegrasikan berbagai situasi sosio-politis dan religius-kultural yang sedang terjadi.

Gagasan pendidikan seni dan konservasi budaya dapat dituangkan ke dalam bentuk baru seperti fenomena inkulturasi yang sudah dijelaskan. Pengupayaan terhadap integrasi 
budaya yang bersifat demokratis, diharapkan kekayaan akan kesenian-kesenian tradisional suatu daerah dengan segala keunikan, keindahan, dan nilai-nilai budayanya dapat dibanggakan, dijaga, dikembangkan, dan dilestarikan. Lebih dari itu juga, keseniankesenian tradisional dapat menjadi suatu bentuk kekuatan dan identitas daerah bahkan bangsa Indonesia dengan falsafah Bhinneka Tunggal Ika untuk menuju suatu keIndonesiaan.

\section{Kesimpulan}

Eksistensi kesenian-kesenian tradisional yang mulai tergerus oleh arus globalisasi secara gradual, menimbulkan kekhawatiran terhadap identitas budaya sehingga dibutuhkan suatu usaha-usaha dalam menjaga keberadaan kesenian itu sendiri. Usaha-usaha tersebut antara lain melalui pendidikan seni dan konservasi budaya yang dapat dituangkan ke dalam bentuk baru seperti inkulturasi. Fenomena inkulturasi mampu memberikan ruang bagi proses pendidikan seni melalui upaya memberikan keahlian berkesenian, kreasi, dan apresiasi menggunakan kesenian tradisional. Selain itu juga adanya konservasi budaya melalui penggunaan kesenian tradisional pada setiap prosesi peribadatan, dapat menjadi suatu kekuatan yang menjiwai, dan secara mendalam memperbaharui kebudayaan tersebut. Pengupayaan proses integrasi budaya yang bersifat demokratis, maka kekayaan keseniankesenian tradisional suatu daerah dengan segala keunikan, keindahan, dan nilai-nilai budayanya dapat dibanggakan, dijaga, dikembangkan dan dilestarikan, serta dapat menjadi identitas suatu daerah bahkan bangsa.

\section{Kepustakaan}

Agustini, Dwi Putri. (2017). Pendidikan Seni: Globalisasi dan Jati Diri Lokal. Dalam Deddy Irawan (Ed.). Paradigma Pendidikan Seni (p. 141-151). Yogyakarta: Thafa Media.

Bakok, Yohanes Don Bosko. (2013). Musik Liturgi Inkulturatif di Gereja Ganjuran Yogyakarta. Resital: Jurnal Seni Pertunjukan, 14(1), 24-32.

Bram Palgunadi. (2002). Serat Kandha Karawitan Jawi. Bandung: Institut Teknologi Bandung.

Chapman, L.H. (1978). Approaches to Art Education. New York: Harcourt Brace Jovanovich.

Eisner, W.E. (1972). Educating Artistic Vision. New York: Macmillan.

Gandhi, Teguh Wangsa. (2011). Filsafat Pendidikan: Mazhab-mazhab Filsafat Pendidikan. Yogyakarta: AR-RUZZ MEDIA.

Hadi, Y. Sumandiyo. (2006). Seni dalam Ritual Agama. Yogyakarta: Pustaka. 
Harahap, Irwansyah. (2001). Etnomusikologi. Jakarta: Diktat Pelatihan Produksi Siaran Musik Etnik di Radio.

Koentjaraningrat. (1990). Pengantar Ilmu Antropologi. Jakarta: PT RINEKA CIPTA.

Lansing, K.M. (1969). Art, Artist, and Art Education. New York: McGraw-Hill Book Company.

Leksono, S.M., Rustaman, Nuryani., Redjeki, Sri. (2013). Kemampuan Profesional Guru Biologi dalam Memahami dan Merancang Model Pembelajaran Konservasi Biodiversitas di SMA. Cakrawala Pendidikan: Jurnal Ilmiah Pendidikan, XXXII(3), 408-419.

Martasudjita. (1998). Memahami Simbol-Simbol dalam Liturgi: Dasar Teologi Liturgi, Makna Simbol, Pakaian, Warna, Ruang, Tahun, dan Musik Liturgi. Yogyakarta: Kanisius.

Martasudjita, E.P.D. (2010). Proses Inkulturasi Liturgi di Indonesia. Studia Philosophica Et Theologica, 10(1), 39-60.

MIPL. (2010). Konservasi. Purwokerto: STMIKAMIKOM.

Muda, Hubertus. (1992). Inkulturasi. Flores: Pustaka Misionalia.

Prier, Karl-Edmund. (2002). Musik Gereja Zaman Sekarang. Yogyakarta: Pusat Musik Liturgi. . (2009). Kamus Musik. Yogyakarta: Pusat Musik Liturgi.

Soehardjo, A.J. (2005). Pendidikan Seni: Dari Konsep Sampai Program. Jurusan Seni dan Desain Universitas Negeri Malang: Balai Kajian Seni dan Desain.

Soeroso. (1985). Pengetahuan Karawitan. Dalam Laporan Pelaksanaan Penulisan Buku/ Diktat Perkuliahan Institut Seni Indonesia Yogyakarta. Yogyakarta: Proyek Peningkatan Pengembangan Institut Seni Indonesia Yogyakarta.

Sugiharto, Bambang. (2013). Musik Dan Misterinya. Dalam Bambang Sugiharto (Ed.). Untuk Apa Seni?. Bandung: Matahari.

Sumarsam. (2003). Gamelan: Interaksi Budaya dan Perkembangan Musikal di Jawa. Yogyakarta: Pustaka Pelajar.

Sunarto. (2014). Kebudayaan Postmodernisme: Percikan Pemikiran Jean Baudrillard. Yogyakarta: PT. Kanisius. 